\title{
Role of trastuzumab emtansine in the treatment of HER2-positive breast cancer
}

\author{
This article was published in the following Dove Press journal: \\ Breast Cancer: Targets and Therapy \\ 23 July 2014 \\ Number of times this article has been viewed
}

\author{
Drew R Oostra' \\ Erin R Macrae ${ }^{2}$ \\ 'Division of Hematology, Oncology, \\ and Transplant. University of \\ Minnesota, Minneapolis, MN, USA; \\ ${ }^{2}$ Division of Medical Oncology, The \\ James Cancer Hospital, The Ohio \\ State University Comprehensive \\ Cancer Center, Columbus, $\mathrm{OH}$, USA
}

\begin{abstract}
Trastuzumab is a monoclonal antibody that is used in the treatment of breast cancer. Trastuzumab targets the human epidermal growth factor receptor 2 (HER2) receptor on breast cancer cells that express this tyrosine kinase receptor. These cancers are referred to as HER2-positive breast cancer. The original studies of trastuzumab showed improved survival in metastatic breast cancer; however, resistance often develops. In the adjuvant setting, women often progress despite therapy that includes trastuzumab. Antibody-drug conjugates are a new class of powerful drugs designed to target high-dose chemotherapy directly to the cancer cells. Trastuzumab emtansine is one of these antibody-drug conjugates and was the first Food and Drug Administration approved drug for a solid tumor. Emtansine is a potent antimicrotubule agent. Trastuzumab is used to target this potent chemotherapy agent directly to the HER2-expressing cancer cells. This review article will summarize the evidence from the preclinical studies, summarize evidence from the clinical trials, discuss current clinical trials, discuss current approval of trastuzumab emtansine, and discuss future directions of research.
\end{abstract}

Keywords: T-DM1, trastuzumab emtansine, Kadcyla ${ }^{\circledR}$, breast cancer, HER2

\section{Introduction}

Breast cancer is divided into different types based upon pathology and biomarkers. Breast cancer cells are evaluated for biomarkers at the time of initial biopsy, including the estrogen receptor status, progesterone receptor status, and human epidermal growth factor receptor 2 (HER2). The status of these receptors is critical in the management of breast cancer. HER2 overexpression is determined by immunohistochemistry of the biopsy sample, and HER2 amplification is analyzed by fluorescence in situ hybridization. ${ }^{1,2}$ HER 2 positivity was associated in the past with a more aggressive breast cancer and with an overall poor prognosis. ${ }^{3}$ However, after the advent of HER2directed therapies, the clinical course of this disease is now similar to patients with HER2-negative breast cancer. ${ }^{4}$

The development of HER2-targeted agents has changed the treatment of HER2positive breast cancer, leading to a dramatic improvement in the lives of women affected by this disease. Trastuzumab, a monoclonal antibody inhibiting HER2, was the first therapeutic antibody targeted at a solid tumor molecular marker to receive US Food and Drug Administration (FDA) approval. ${ }^{5}$ Trastuzumab improves overall survival (OS) in both early-stage and metastatic breast cancer (MBC); however, tumor progression after exposure to trastuzumab continues to occur. ${ }^{6,7}$ Antibody-drug conjugates (ADCs) are a new class of powerful drugs designed to target high-dose chemotherapy directly to the cancer cells. Trastuzumab emtansine (T-DM1) is one ADC that targets HER2
Correspondence: Erin R Macrae

B407 Starling Loving Hall,

320 W I0th Ave, Columbus,

$\mathrm{OH}$, USA 43212

Tel + I 6I4366854|

Email erin.macrae@osumc.edu
Breast Cancer: Targets and Therapy 2014:6 103-113

Dovepress

http://dx.doi.org// 0.2147/BCTT.S67297 (c) (i) (5) 2014 Oostra and Macrae. This work is published by Dove Medical Press Limited, and licensed under Creative Commons Attribution - Non Commercial (unported, v3.0) License. The full terms of the License are avalable at http://creativecommons.org/licenses/by-nc/3.0/. Non-commercial uses of the work are permitted without any further permission from Dove Medical Press Limited, provided the work is properly attributed. Permissions beyond the scope of the License are administered by Dove Medical Press Limited. Information on how to request permission may be found at http://www.dovepress.com/permissions.php 
and has been shown to cause significant improvements in progression-free survival (PFS) in patients with prior progression on anti-HER2 agents. ${ }^{8,9}$ This article will review the history, development, and role of T-DM1 in the treatment of HER2-positive breast cancer.

\section{History of anti-HER2 therapy prior to T-DMI}

HER2 is a member of the HER family of transmembrane tyrosine kinase receptors, which also includes human epidermal growth factor receptor 1 (HER1), human epidermal growth factor receptor 3 (HER3), and human epidermal growth factor receptor 4 (HER4). This family of receptors normally regulates cell growth, differentiation, and survival. ${ }^{10,11}$ This protein family is characterized by an extracellular binding domain, transmembrane section, and intracellular tyrosine kinase domain. The noteworthy exception is HER3, which does not possess an intracellular domain. HER1, HER3, and HER4 are stimulated by receptorspecific ligands. ${ }^{12}$ Homodimerization or heterodimerization of the HER proteins leads to phosphorylation of the tyrosine kinase domain, which leads to cell proliferation and survival signaling. HER2 is the favored dimerization component for the other HER family members. ${ }^{12}$ HER2 can assume a fixed conformation resembling a ligand-activated state, permitting it to dimerize without a ligand; this is known as ligandindependent dimerization. ${ }^{12}$

HER2 overexpression and/or amplification occurs in approximately $15 \%-30 \%$ of breast cancers. ${ }^{2,4,13}$ Even when the cancer progresses on HER2-targeted therapy, the tumors still rely on HER2 and its downstream pathway; this is consistent with the oncogene addiction model. ${ }^{14}$ In 1987, Slamon et al reported that the amplification of the HER2 oncogene correlates with shorter time to relapse and lower survival rate in women with breast cancer. ${ }^{3}$ Slamon et $\mathrm{al}^{3}$ demonstrated that a monoclonal antibody against HER2 inhibited the growth of breast tumor-derived cell lines that overexpress the HER2 gene. In the early 1990s, Genentech created trastuzumab (Herceptin ${ }^{\circledR}$ ) from Chinese hamster ovary cells. ${ }^{5}$ Trastuzumab is the humanized monoclonal antibody directed against the extracellular domain of HER2. ${ }^{16}$ The clinical trials studying the clinical effects of trastuzumab began in 1992. After demonstrating promising efficacy in early clinical trials, the seminal Phase III clinical trial by Slamon et al showed a marked improvement in PFS of 7.4 months in patients treated with trastuzumab and chemotherapy compared to 4.6 months with chemotherapy alone $(P<0.001) .{ }^{17}$ OS was also superior in patients treated with trastuzumab compared to the non-trastuzumab arm, with a median survival of 25.1 months versus 20.3 months, respectively $(P=0.046) .{ }^{12,17}$ In 1998 , trastuzumab received FDA approval for the treatment of HER2-positive MBC in combination with paclitaxel for first-line treatment and was approved as a single agent for second- and third-line therapy. ${ }^{5}$ Similarly, trastuzumab improved disease-free survival and OS in patients with early-stage breast cancer leading to its FDA approval for stage I-III HER2-positive breast cancer in 2006 (when combined with chemotherapy) and in 2008 (as a stand-alone medication). ${ }^{6,18}$

\section{Mechanism of action for trastuzumab}

It is clear that trastuzumab works, but the mechanism of action is less clear. Trastuzumab causes antitumor activity through a variety of potential mechanisms of action. Binding of trastuzumab to HER2 reduces cleavage of the extracellular domain and thereby prevents phosphorylation of $\mathrm{p} 95 .^{12}$ Trastuzumab may also reduce downstream signaling by inhibiting the homodimerization or heterodimerization of HER2. ${ }^{12}$ Trastuzumab may use the Fc (humanized) portion to activate antibody-dependent cell-mediated cytotoxicity. Trastuzumab may lead to inhibition of HER2-regulated angiogenesis. Lastly, it has been postulated that trastuzumab can cause endocytosis of the HER2 receptor leading to HER2 degradation. $^{12}$

HER2-directed therapy led to a dramatic improvement in the prognosis of HER2-amplified MBC patients, with the median OS now exceeding 3 years. ${ }^{19}$ Despite the significant impact made by trastuzumab in the treatment of HER2positive $\mathrm{MBC}$, most patients will ultimately experience disease progression. One hypothesis as to the dramatic improvement in OS recently is the use of sequential HER2blockade to treat this disease. Tumors that overexpress HER2 continue to derive benefit from additional anti-HER2 therapy after progression on trastuzumab, with a median time to progression of 5.2-7.2 months on up to six lines of therapy. ${ }^{19}$

Dual HER2 inhibition - the administration of two antiHER2 agents simultaneously - may lead to more durable tumor response than sequential HER2 therapy. ${ }^{14}$ Pertuzumab is a monoclonal antibody that targets the dimerization domain of HER2. When given in combination with trastuzumab, pertuzumab leads to an improvement in PFS in patients with metastatic HER2-positive breast cancer. ${ }^{20}$ Similarly, lapatinib is a tyrosine kinase inhibitor that blocks intracellular tyrosine kinase function in HER1 and HER2. Lapatinib and trastuzumab can lead to dramatic responses in patients with prior 
progression on trastuzumab-based therapy. ${ }^{21,22}$ ADCs may be considered a form of dual therapy as well. In the example of T-DM1, the antibody portion of the conjugate retains the anti-HER2 effects, while the chemotherapy portion of the conjugate inhibits cell division.

\section{ADCs}

ADCs are a relatively new development. These new therapies are comprised of three primary components: the antibody, the linker, and the cytotoxic agent. In theory, by combining these two different categories, targeted delivery should be achieved with the ability to use more potent chemotherapeutic agents. To date, three ADCs have been approved by the FDA: gemtuzumab ozogamicin, brentuximab vedotin, and T-DM1. Gemtuzumab ozogamicin was initially FDAapproved in 2000 for the treatment of relapsed CD33-positive acute myeloid leukemia in older patients not considered candidates for standard chemotherapy. ${ }^{23}$ However, it was recently withdrawn from the market after further studies showed no benefit. ${ }^{24}$ Brentuximab vedotin was approved in 2011 for the treatment of relapsed or refractory Hodgkin's lymphoma and relapsed or refractory systemic anaplastic large-cell lymphoma. ${ }^{25,26}$ Finally, the most recent newcomer to this subclass of agents is T-DM1 for use in metastatic HER2-positive breast cancer. ${ }^{27}$

\section{T-DMI mechanism of action}

T-DM1 is comprised of the antibody trastuzumab, covalently linked through a thioether molecular bond to the antimicrotubule chemotherapy emtansine (DM1). ${ }^{28}$ The mechanism of action of T-DM1 is two-fold, both a direct antitumor effect from trastuzumab as well as a cytotoxic chemotherapy effect from the DM1 component. Trastuzumab retains all of its mechanisms of action, which were previously mentioned. ${ }^{12,29}$ The most important aspect of using trastuzumab is that it can be used to deliver chemotherapy specifically to HER2positive breast cancer tumor cells. By directly transporting cytotoxic agents to cancer cells, this both limits toxicity on other nonmalignant tissue and allows for the utilization of more potent chemotherapy (See Figure 1). ${ }^{30}$

DM1 is the chemotherapy agent used in T-DM1. It is a derivative of maytansine collected from plants and mosses, and primarily prevents tumor growth by inhibiting tubulin development of the mitotic spindle and cell division. ${ }^{31}$ This chemotherapeutic agent is not routinely used in oncology practices due to the side effect profile caused by a small therapeutic window, as DM1 is approximately 100 times more potent than vincristine. ${ }^{32,33}$ The linker of the antibody and cytotoxic drug is very important. If the link is too unstable, then the drug will be delivered to the blood stream and peripheral tissues. If the link is too strong, then it may not be able to be cleaved. ${ }^{28,34}$ Overall, these ADCs are very complex and often very difficult to develop.

\section{Preclinical studies with T-DMI}

Lewis Phillips et al did much of the preclinical work on T-DM1; they determined in vitro and in vivo efficacy, pharmacokinetics, and toxicity of T-DM1. ${ }^{34}$ Lewis Phillips et al used both disulfide and thioether linkers, but were surprised to find that trastuzumab linked to DM1 through a non-reducible thioether linkage displayed superior activity when compared with trastuzumab linked through disulfide linkers. ${ }^{34,35}$ It was thought that highly reducible linkers (disulfide) would allow for endosomal reduction and more rapid effect; however, this also led to more rapid clearance. In fact, it is thought that the thioether linker is internalized and undergoes proteolytic degradation, leading to an active metabolite that lasts longer. ${ }^{30,34-36}$

T-DM1 was evaluated in normal cell lines (MCF10A breast epithelial cells) and tumor cell lines (breast carcinoma BT-474, SK-BR-3, MCF7, MDA-MB-468, MDA-MB-361, and HCC1954; lung carcinoma Calu 3; and ovarian carcinoma line SK-OV-3). The cell lines with HER2 overexpression (BT-474, SK-BR-3, and MCF7) responded well to T-DM1; while the cell lines without HER2 overexpression (MDA-MB-468) were unaffected. The cell cycle was also analyzed and found to be arrested in the G2-M phase. In HER2-overexpressiong breast cancer mouse models, complete tumor regression was seen for the duration of the study (126 days). T-DM1 was also active in trastuzumabrefractory tumors. Trastuzumab alone caused an initial decrease in tumor size followed by regrowth upon cessation of treatment. ${ }^{34,36}$

A concern in the development of T-DM1 is that the ADC would disrupt the mechanisms of action of trastuzumab. This was studied in preclinical studies by Junttila et al. ${ }^{29}$ They reported that T-DM1 did not affect the mechanism of action of trastuzumab itself. This was studied in cell lines with HER2 overexpression and in the HER2 transgenic mouse model. ${ }^{29}$

In further preclinical studies, T-DM1 toxicity was assessed in rats and was measured by body weight loss. The toxicity in rats was negligible compared to free DM1 or trastuzumab linked to DM1 through a reducible linker. ${ }^{34}$ Other key safety findings from cynomolgus monkey studies showed reversible increases in hepatic transaminases, 
dose-dependent irreversible axonal degeneration, and modest reversible decreases in platelet counts. ${ }^{37}$

\section{Phase I clinical trials}

After the extensive preclinical work, Phase I clinical trials are conducted to characterize the pharmacokinetics, safety, and maximum tolerated dose (MTD) of the drug. We will discuss the Phase I clinical trials conducted in patients with advanced HER2-positive MBC. These trials are also summarized in Table 1.

Krop et $\mathrm{al}^{38}$ conducted a Phase I study in 24 patients with HER2-positive MBC whose disease had progressed on earlier trastuzumab-based therapy (median of four prior chemotherapeutic agents). The tolerability and safety of T-DM1 was assessed when administered every 3 weeks by intravenous infusion over 30-90 minutes. Patients received doses at $0.3 \mathrm{mg} / \mathrm{kg}$ to $4.8 \mathrm{mg} / \mathrm{kg}$. Grade 4 thrombocytopenia was dose-limiting at $4.8 \mathrm{mg} / \mathrm{kg}$. The investigators deemed the MTD to be $3.6 \mathrm{mg} / \mathrm{kg}$. T-DM1's volume of distribution was $60 \pm 3.6 \mathrm{~mL} / \mathrm{kg}$ at the MTD. The half-life of T-DM1 at the MTD was 3.5 days. The clearance of T-DM1 was $12.9 \pm 3.4 \mathrm{~mL} / \mathrm{day} / \mathrm{kg}$ at the MTD. In patients with measurable disease treated with the MTD, the response rate to T-DM1 was $44 \%$ (four out of nine). Overall, the confirmed response rate was $25 \%$ (six of 24). Other notable adverse events included grade 2 thrombocytopenia, elevated transaminases, anemia, nausea, and fatigue. Thrombocytopenia was seen in almost all patients receiving T-DM1 at doses $>1.2 \mathrm{mg} / \mathrm{kg}$. No cardiac effects requiring dose modification were reported. ${ }^{38}$

Beeram et $\mathrm{al}^{39}$ released further data in 2012 from the abovementioned multicenter, dose-escalation study. Additional patients were enrolled at the MTD. Twenty-eight patients were included in the analysis. The MTD was 2.4 $\mathrm{mg} / \mathrm{kg}$. Overall, it was well-tolerated and few modifications or discontinuations were needed. Objective partial tumor responses were reported in $13(46.4 \%)$ patients. The median duration of response was 18.6 months. This Phase I clinical trial concluded that weekly T-DM1 at $2.4 \mathrm{mg} / \mathrm{kg}$ also had clinical effect and was well-tolerated. ${ }^{39}$

\section{Phase II clinical trials}

Based on the exciting preliminary efficacy results presented in the Phase I clinical trials, T-DM1 moved on to Phase II development. The MTD of T-DM1 $(3.6 \mathrm{mg} / \mathrm{kg}$ every 3 weeks) from the 2010 published paper was selected as the recommended Phase II dose. There have been three main Phase II clinical trials published to date. These trials are also summarized in Table 2 .

Burris et al conducted a Phase II clinical trial with 112 patients with HER2-positive MBC with tumor progression after prior HER2-directed therapy. ${ }^{40}$ Treated with T-DM1 at $3.6 \mathrm{mg} / \mathrm{kg}$ every 3 weeks, patients were evaluated for efficacy every 3 months. After 12 months follow-up, the response rate was $25.9 \%$. Median PFS was 4.6 months. T-DM1 was well-tolerated with the majority of adverse events grade 1-2. The most common grade 3 adverse events were hypokalemia $(8.9 \%)$, thrombocytopenia $(8.0 \%)$, and fatigue $(4.5 \%){ }^{40}$

Another Phase II clinical trial was conducted by Krop et al in which 110 patients with HER2-overexpressing MBC with prior exposure to trastuzumab, lapatinib, an anthracycline, a taxane, and capecitabine. ${ }^{41}$ Patients were administered with T-DM1 at $3.6 \mathrm{mg} / \mathrm{kg}$ every 3 weeks. T-DM1 therapy showed an overall response rate of $34.5 \%$. The median PFS was 7.3 months. It was concluded that it was well-tolerated at the recommended Phase II dose. Again, most adverse events were grade $1-2$. Similar to the Burris et al study, ${ }^{40}$ the most frequent grade 3 adverse events encountered were thrombocytopenia $(9.1 \%)$, fatigue $(4.5 \%)$, and cellulitis $(3.6 \%) .{ }^{41}$

Lastly, another clinical Phase II trial was conducted by Hurvitz et al. ${ }^{42}$ Patients were randomly assigned to either first-line T-DM1 or first-line trastuzumab plus docetaxel. One hundred thirty-seven patients with HER2-positive MBC or recurrent locally advanced breast cancer were included in the analysis. Patients continued on the therapy until disease progression or toxicity. Median follow-up was 14 months for both arms. Women were administered T-DM1 at $3.6 \mathrm{mg} / \mathrm{kg}$ every 3 weeks. Median PFS was 9.2 months with trastuzumab plus docetaxel compared to 14.2 months with T-DM1. The overall response rate was $58.0 \%$ and $64.2 \%$

Table I Summary of Phase I clinical trials

\begin{tabular}{|c|c|c|c|c|c|c|c|}
\hline Authors & Year & $\begin{array}{l}\text { Number } \\
\text { of patients }\end{array}$ & Study design & $\begin{array}{l}\text { Dose } \\
\text { escalation }\end{array}$ & $\begin{array}{l}\text { Dosing } \\
\text { frequency }\end{array}$ & $\begin{array}{l}\text { Grade } 3 \text { or } 4 \\
\text { adverse events }\end{array}$ & $\begin{array}{l}\text { Maximum } \\
\text { tolerated dose }\end{array}$ \\
\hline Krop et $\mathrm{al}^{38}$ & 2010 & 24 & Phase I single-arm & $0.3-4.8 \mathrm{mg} / \mathrm{kg}$ & Every 3 weeks & $\begin{array}{l}\text { Thrombocytopenia, } \\
\text { pulmonary hypertension }\end{array}$ & $\begin{array}{l}3.6 \mathrm{mg} / \mathrm{kg} \text { every } \\
3 \text { weeks }\end{array}$ \\
\hline Beeram et $\mathrm{al}^{39}$ & 2012 & 28 & $\begin{array}{l}\text { Phase I single-arm with } \\
\text { additional patients added } \\
\text { later at maximum dose }\end{array}$ & $1.2-2.9 \mathrm{mg} / \mathrm{kg}$ & Weekly & Thrombocytopenia & $2.4 \mathrm{mg} / \mathrm{kg}$ weekly \\
\hline
\end{tabular}


Table 2 Summary of Phase II clinical trials

\begin{tabular}{|c|c|c|c|c|c|c|c|}
\hline Author & Year & $\begin{array}{l}\text { Number } \\
\text { of patients }\end{array}$ & Study design & Study population & $\begin{array}{l}\text { Objective } \\
\text { response } \\
\text { rate }\end{array}$ & $\begin{array}{l}\text { Progression- } \\
\text { free survival }\end{array}$ & $\begin{array}{l}\text { Grade } 3 \text { adverse } \\
\text { events }\end{array}$ \\
\hline Burris et a ${ }^{40}$ & 2010 & 112 & $\begin{array}{l}\text { Phase II single- } \\
\text { arm }\end{array}$ & $\begin{array}{l}\text { HER2-positive MBC who had } \\
\text { tumor progression after prior } \\
\text { HER2-directed therapy or } \\
\text { received prior chemotherapy }\end{array}$ & $25.90 \%$ & 4.6 months & $\begin{array}{l}\text { Hypokalemia ( } 8.9 \%) \text {, } \\
\text { thrombocytopenia (8.0\%), } \\
\text { and fatigue (4.5\%) }\end{array}$ \\
\hline Krop et al ${ }^{41}$ & 2012 & 110 & $\begin{array}{l}\text { Phase II single- } \\
\text { arm }\end{array}$ & $\begin{array}{l}\text { HER2-positive MBC who } \\
\text { had prior treatment with } \\
\text { trastuzumab, lapatinib, an } \\
\text { anthracycline, a taxane, } \\
\text { and capecitabine }\end{array}$ & $34.50 \%$ & 7.3 months & $\begin{array}{l}\text { Thrombocytopenia }(9.1 \%) \text {, } \\
\text { fatigue }(4.5 \%) \text {, and } \\
\text { cellulitis }(3.6 \%)\end{array}$ \\
\hline \multirow[t]{3}{*}{ Hurvitz et $\mathrm{al}^{42}$} & 2013 & 137 & $\begin{array}{l}\text { Phase II } \\
\text { randomized to: }\end{array}$ & $\begin{array}{l}\text { HER2-positive MBC or } \\
\text { recurrent locally advanced } \\
\text { breast cancer }\end{array}$ & & & \\
\hline & & & T-DMI versus & First-line treatment & $64.20 \%$ & I4.2 months & $46.40 \%$ \\
\hline & & & $\begin{array}{l}\text { trastuzumab } \\
\text { plus docetaxel }\end{array}$ & First-line treatment & $58.00 \%$ & 9.2 months & $90.90 \%$ \\
\hline
\end{tabular}

Abbreviations: HER2, human epidermal growth factor receptor 2; MBC, metastatic breast cancer; T-DMI, trastuzumab emtansine.

with trastuzumab plus docetaxel and T-DM1, respectively. In addition to an improved efficacy of T-DM1 over trastuzumab plus chemotherapy in the first-line setting for patients with advanced HER2-positive breast cancer, this study also reported a more favorable safety profile favoring T-DM1. Grade 3 adverse events were present in 46.4\% of T-DM1treated patients versus $90.9 \%$ in trastuzumab-plus-docetaxeltreated patients. Grade 3 or 4 adverse events for T-DM1 included: neutropenia (5.8\%), thrombocytopenia (7.2\%), anemia (2.9\%), fatigue (4.3\%), nausea/vomiting (2.9\%), increased aspartate aminotransferase $(8.7 \%)$, increased alanine aminotransferase (ALT) (10.1\%), back pain (1.4\%), and pneumonia (5.8\%). Adverse events leading to discontinuation of treatment were present in $7.2 \%$ of T-DM1-treated patients versus $40.9 \%$ in trastuzumab-plus-docetaxel-treated patients. Serious adverse events were present in $20.3 \%$ of T-DM1-treated patients versus $25.8 \%$ in trastuzumab-plusdocetaxel-treated patients. ${ }^{42}$

\section{Phase III clinical trials}

Given the results of the efficacy and safety of T-DM1 in MBC in the Phase II clinical trials, the Phase III clinical trials were conducted to characterize the value of T-DM1 in clinical practice. To date, there is one Phase III clinical trial with published results utilizing T-DM1. Phase III clinical trials that have completed patient accrual without public results or studies that are ongoing are listed in Table 3.

The EMILIA trial was a randomized and multicenter Phase III trial in which 991 patients with HER2-positive locally advanced breast cancer or MBC who were previously treated with trastuzumab and a taxane were included. ${ }^{8}$ Patients were randomly assigned to T-DM1 $(3.6 \mathrm{mg} / \mathrm{kg}$ intravenously) or lapatinib (1,250 mg orally daily) plus capecitabine $\left(1,000 \mathrm{mg} / \mathrm{m}^{2}\right.$ orally twice a day, days 1 to 14$)$. Median PFS was 9.6 months with T-DM1 and 6.4 months with lapatinib plus capecitabine. The objective response rate was $43.6 \%$ with T-DM1 and $30.8 \%$ with lapatinib plus capecitabine. The rates of grade 3 or 4 adverse events were $41 \%$ with T-DM1 and 57\% with lapatinib plus capecitabine. T-DM1 did have a higher incidence of thrombocytopenia and increased serum aminotransferases. However, lapatinib plus capecitabine had higher incidence of diarrhea, nausea, vomiting, and palmar-plantar erythrodysesthesia. The authors concluded that T-DM1 significantly prolonged PFS and OS with less toxicity.

\section{FDA approval of T-DMI}

Based on the EMILIA clinical trial, the FDA approved T-DM1 on February 22, 2013. ${ }^{27}$ It was approved for patients with HER2-positive MBC who previously received trastuzumab and a taxane (separately or in combination). Patients should have either: received prior therapy for metastatic disease, or developed disease recurrence during or within 6 months of completing adjuvant therapy. ${ }^{43}$ The trade name of T-DM1 is Kadcyla ${ }^{\circledR}$. Kadcyla was approved with the generic name "adotrastuzumab emtansine". The FDA recommends that health care professionals use the FDA-approved proprietary name (Kadcyla) and its nonproprietary name (ado-trastuzumab emtansine) when communicating medication orders or in electronic order entry systems. ${ }^{44}$ This is to help reduce the 
Table 3 Summary of clinical trials currently underway

\begin{tabular}{|c|c|c|c|c|c|c|}
\hline $\begin{array}{l}\text { ClinicalTrials. } \\
\text { gov identifier }\end{array}$ & Phase & Name & Status & Sponsor & $\begin{array}{l}\text { Number } \\
\text { of patients }\end{array}$ & Study design \\
\hline NCT0I8I6035 & I & N/A & Not open yet & $\begin{array}{l}\text { University of } \\
\text { Washington }\end{array}$ & $\begin{array}{l}20 \\
\text { (estimated) }\end{array}$ & $\begin{array}{l}\text { HER2-positive MBC or locally advanced breast } \\
\text { cancer that cannot be removed by surgery. }\end{array}$ \\
\hline NCT020380I0 & I & N/A & $\begin{array}{l}\text { Currently } \\
\text { recruiting }\end{array}$ & $\begin{array}{l}\text { Northwestern } \\
\text { University }\end{array}$ & $\begin{array}{l}28 \\
\text { (estimated) }\end{array}$ & $\begin{array}{l}\text { To assess combination of T-DMI and BYL7I9 } \\
\text { for safety and efficacy in treating MBC. }\end{array}$ \\
\hline NCT0I5I3083 & I & $\mathrm{N} / \mathrm{A}$ & $\begin{array}{l}\text { Currently } \\
\text { recruiting }\end{array}$ & $\begin{array}{l}\text { Hoffmann-La } \\
\text { Roche }\end{array}$ & $\begin{array}{l}30 \\
\text { (estimated) }\end{array}$ & $\begin{array}{l}\text { HER2-positive MBC with normal or reduced } \\
\text { hepatic function. }\end{array}$ \\
\hline NCT00934856 & I & $\mathrm{N} / \mathrm{A}$ & Completed & $\begin{array}{l}\text { Hoffmann-La } \\
\text { Roche }\end{array}$ & 99 & $\begin{array}{l}\text { Adding T-DMI to docetaxel in patients with } \\
\text { locally advanced or HER2-positive MBC. For } \\
\text { patients with locally advanced breast cancer, } \\
\text { pertuzumab may be added to T-DMI and } \\
\text { docetaxel. }\end{array}$ \\
\hline NCT00928330 & 1 & N/A & Completed & Genentech & 57 & $\begin{array}{l}\text { Oral GDC } 094 \text { I administered in combination } \\
\text { with either IV infusion of T-DMI or IV infusion } \\
\text { of trastuzumab. }\end{array}$ \\
\hline NCT0I5I3083 & 1 & N/A & $\begin{array}{l}\text { Currently } \\
\text { recruiting }\end{array}$ & $\begin{array}{l}\text { Hoffmann-La } \\
\text { Roche }\end{array}$ & $\begin{array}{l}30 \\
\text { (estimated) }\end{array}$ & $\begin{array}{l}\text { Evaluate the pharmacokinetics and safety of } \\
\text { T-DMI in patients with HER2-positive MBC } \\
\text { and normal or reduced hepatic function. }\end{array}$ \\
\hline NCT020739I6 & I & STELA & $\begin{array}{l}\text { Currently } \\
\text { recruiting }\end{array}$ & $\begin{array}{l}\text { The Methodist } \\
\text { Hospital System }\end{array}$ & $\begin{array}{l}\text { I8 } \\
\text { (estimated) }\end{array}$ & $\begin{array}{l}\text { Assess the safety and tolerability of combining } \\
\text { T-DMI with lapatinib and abraxane in patients } \\
\text { with HER2-positive MBC. }\end{array}$ \\
\hline NCTOI98350I & $\mathrm{lb}$ & $\mathrm{N} / \mathrm{A}$ & $\begin{array}{l}\text { Currently } \\
\text { recruiting }\end{array}$ & Oncothyreon Inc. & $\begin{array}{l}48 \\
\text { (estimated) }\end{array}$ & $\begin{array}{l}\text { Determine the maximum tolerated dose or } \\
\text { recommended dose and assess the safety and } \\
\text { tolerability of ONT- } 380 \text { combined with T-DMI } \\
\text { in patients with HER2-positive breast cancer. }\end{array}$ \\
\hline NCT01976I69 & $\mathrm{lb}$ & $\mathrm{N} / \mathrm{A}$ & Not yet open & $\begin{array}{l}\text { University of Texas } \\
\text { Southwestern } \\
\text { Medical Center }\end{array}$ & $\begin{array}{l}17 \\
\text { (estimated) }\end{array}$ & $\begin{array}{l}\text { Phase Ib inter-patient dose-escalation study } \\
\text { of PD-033299I in combination with T-DMI in } \\
\text { patients with recurrent or metastatic HER2- } \\
\text { positive breast cancer after prior trastuzumab } \\
\text { or other HER2-directed therapies. }\end{array}$ \\
\hline NCT0095I 665 & Ib-lla & N/A & Completed & Genentech & 107 & $\begin{array}{l}\text { T-DMI, paclitaxel, and pertuzumab in patients } \\
\text { with HER2-positive locally advanced breast } \\
\text { cancer or MBC. }\end{array}$ \\
\hline NCTOI 702558 & I and II & N/A & $\begin{array}{l}\text { Currently } \\
\text { recruiting }\end{array}$ & Hoffmann-La Roche & $\begin{array}{l}240 \\
\text { (estimated) }\end{array}$ & $\begin{array}{l}\text { Maximum tolerated dose of capecitabine in } \\
\text { combination with T-DMI in patients with HER2- } \\
\text { positive MBC or locally advanced or metastatic } \\
\text { gastric cancer using a Phase I design, followed } \\
\text { by a Phase II single-arm study to explore the } \\
\text { efficacy of the combination in MBC patients. }\end{array}$ \\
\hline NCT02070094 & I and II & $\mathrm{N} / \mathrm{A}$ & $\begin{array}{l}\text { Currently } \\
\text { recruiting }\end{array}$ & $\begin{array}{l}\text { Ukrainian } \\
\text { Antitumor Center }\end{array}$ & $\begin{array}{l}80 \\
\text { (estimated) }\end{array}$ & $\begin{array}{l}\text { A Phase I/II study of T-DMI plus ABT- } 737 \text { in } \\
\text { treating patients with HER2-positive breast } \\
\text { cancer. }\end{array}$ \\
\hline NCTOII 96052 & II & $\mathrm{N} / \mathrm{A}$ & $\begin{array}{l}\text { Ongoing, not } \\
\text { recruiting } \\
\text { anymore }\end{array}$ & Hoffmann-La Roche & 153 & $\begin{array}{l}\text { T-DMI after the completion of anthracycline- } \\
\text { based adjuvant/neoadjuvant chemotherapy in } \\
\text { patients with early HER2-positive breast cancer. }\end{array}$ \\
\hline NCT0I975I42 & II & N/A & $\begin{array}{l}\text { Currently } \\
\text { recruiting }\end{array}$ & Institut Curie & $\begin{array}{l}480 \\
\text { (estimated) }\end{array}$ & $\begin{array}{l}\text { Patients with MBC considered HER2-negative are } \\
\text { screened for HER2-amplified circulating tumor } \\
\text { cells. If HER2-amplified circulating tumor cells are } \\
\text { detected, patients are treated with T-DMI. }\end{array}$ \\
\hline NCTOI 853748 & II & ATEMPT & $\begin{array}{l}\text { Currently } \\
\text { recruiting }\end{array}$ & $\begin{array}{l}\text { Dana-Farber } \\
\text { Cancer Institute }\end{array}$ & $\begin{array}{l}500 \\
\text { (estimated) }\end{array}$ & $\begin{array}{l}\text { T-DMI }(\times \mid 7) \text { versus paclitaxel }(\text { weekly } \times 12) / \\
\text { trastuzumab (every } 3 \text { weeks } \times 13) \text { for stage I } \\
\text { (small) HER2-positive breast cancer. }{ }^{50}\end{array}$ \\
\hline NCT0I745965 & II & $\mathrm{N} / \mathrm{A}$ & $\begin{array}{l}\text { Currently } \\
\text { recruiting }\end{array}$ & $\begin{array}{l}\text { West German } \\
\text { Study Group }\end{array}$ & $\begin{array}{l}380 \\
\text { (estimated) }\end{array}$ & $\begin{array}{l}\text { Preoperative T-DMI with or without standard } \\
\text { endocrine therapy versus trastuzumab with } \\
\text { standard endocrine therapy given for } 12 \text { weeks } \\
\text { in patients with operable HER2-positive/HR+ } \\
\text { breast cancer within the ADAPT protocol. }\end{array}$ \\
\hline
\end{tabular}


Table 3 (Continued)

\begin{tabular}{|c|c|c|c|c|c|c|}
\hline $\begin{array}{l}\text { ClinicalTrials. } \\
\text { gov identifier }\end{array}$ & Phase & Name & Status & Sponsor & $\begin{array}{l}\text { Number } \\
\text { of patients }\end{array}$ & Study design \\
\hline NCT0078I6I2 & II & $\mathrm{N} / \mathrm{A}$ & $\begin{array}{l}\text { Enrolling } \\
\text { participants } \\
\text { by invitation } \\
\text { only }\end{array}$ & Genentech & $\begin{array}{l}720 \\
\text { (estimated) }\end{array}$ & $\begin{array}{l}\text { Patients receiving single-agent T-DMI } \\
\text { or combination T-DMI administered } \\
\text { in combination with paclitaxel or with } \\
\text { pertuzumab } \pm \text { paclitaxel. }\end{array}$ \\
\hline NCT0I835236 & II & N/A & $\begin{array}{l}\text { Currently } \\
\text { recruiting }\end{array}$ & $\begin{array}{l}\text { Swiss Group for } \\
\text { Clinical Cancer } \\
\text { Research }\end{array}$ & $\begin{array}{l}208 \\
\text { (estimated) }\end{array}$ & $\begin{array}{l}\text { Trastuzumab and pertuzumab followed by } \\
\text { T-DMI in MBC. }\end{array}$ \\
\hline NCT0I5974I4 & II & N/A & $\begin{array}{l}\text { Currently } \\
\text { recruiting }\end{array}$ & EORTC & $\begin{array}{l}80 \\
\text { (estimated) }\end{array}$ & $\begin{array}{l}\text { Elderly MBC: pertuzumab-Herceptin } \\
\text { versus pertuzumab-Herceptin-metronomic } \\
\text { chemotherapy, followed by T-DMI. }\end{array}$ \\
\hline NCT02073487 & II & $N / A$ & $\begin{array}{l}\text { Currently } \\
\text { recruiting }\end{array}$ & $\begin{array}{l}\text { The Methodist } \\
\text { Hospital System }\end{array}$ & $\begin{array}{l}30 \\
\text { (estimated) }\end{array}$ & $\begin{array}{l}\text { Evaluate the pathological CR when T-DMI } \\
\text { and lapatinib and abraxane are combined } \\
\text { in newly diagnosed HER2-positive breast } \\
\text { cancer. }\end{array}$ \\
\hline NCT0I565200 & II & ZEPHIR & $\begin{array}{l}\text { Ongoing, not } \\
\text { recruiting } \\
\text { anymore }\end{array}$ & $\begin{array}{l}\text { Jules Bordet } \\
\text { Institute }\end{array}$ & $\begin{array}{l}60 \\
\text { (estimated) }\end{array}$ & $\begin{array}{l}\text { HER2 imaging study to identify HER2-positive } \\
\text { MBC patients unlikely to benefit from T-DMI. }\end{array}$ \\
\hline NCTOI904903 & II & SAFE-HEaRt & $\begin{array}{l}\text { Currently } \\
\text { recruiting }\end{array}$ & $\begin{array}{l}\text { Washington } \\
\text { Hospital Center }\end{array}$ & $\begin{array}{l}33 \\
\text { (estimated) }\end{array}$ & $\begin{array}{l}\text { Cardiac safety study in patients with HER2- } \\
\text { positive breast cancer. }\end{array}$ \\
\hline NCT0I70257I & III & N/A & $\begin{array}{l}\text { Currently } \\
\text { recruiting }\end{array}$ & Hoffmann-La Roche & $\begin{array}{l}2,220 \\
\text { (estimated) }\end{array}$ & $\begin{array}{l}\text { T-DMI in patients with HER2-positive locally } \\
\text { advanced breast cancer or MBC who have } \\
\text { received prior anti-HER2 and chemotherapy- } \\
\text { based treatment. Patients will receive } 3.6 \mathrm{mg} / \mathrm{kg} \\
\text { T-DMI intravenously every } 3 \text { weeks until } \\
\text { unacceptable toxicity, withdrawal of consent, or } \\
\text { disease progression. }\end{array}$ \\
\hline NCTOI772472 & III & KATHERINE & $\begin{array}{l}\text { Currently } \\
\text { recruiting }\end{array}$ & Hoffmann-La Roche & $\begin{array}{l}\mathrm{I}, 484 \\
\text { (estimated) }\end{array}$ & $\begin{array}{l}\text { T-DMI versus trastuzumab as adjuvant therapy } \\
\text { in patients with HER2-positive breast cancer } \\
\text { who have residual tumor present in the breast } \\
\text { or axillary lymph nodes following preoperative } \\
\text { therapy. Radiotherapy and/or hormone therapy } \\
\text { will be given in addition if indicated. }{ }^{49}\end{array}$ \\
\hline NCTOII 20184 & III & MARIANNE & $\begin{array}{l}\text { Ongoing, not } \\
\text { recruiting } \\
\text { anymore }\end{array}$ & Hoffmann-La Roche & 1,095 & $\begin{array}{l}\text { T-DMI with pertuzumab or T-DMI with } \\
\text { pertuzumab-placebo (blinded for pertuzumab), } \\
\text { versus the combination of trastuzumab plus } \\
\text { taxane (docetaxel or paclitaxel) in patients with } \\
\text { HER2-positive progressive or recurrent locally } \\
\text { advanced or previously untreated MBC. }{ }^{48}\end{array}$ \\
\hline NCTOI4I9I97 & III & TH3RESA & $\begin{array}{l}\text { Ongoing, not } \\
\text { recruiting } \\
\text { anymore }\end{array}$ & Hoffmann-La Roche & 604 & $\begin{array}{l}\text { T-DMI in comparison with treatment of the } \\
\text { physician's choice in patients with metastatic or } \\
\text { unresectable locally advanced/recurrent HER2- } \\
\text { positive breast cancer.' }\end{array}$ \\
\hline NCT0I96647I & III & KAITLIN & $\begin{array}{l}\text { Currently } \\
\text { recruiting }\end{array}$ & Hoffmann-La Roche & $\begin{array}{l}2,500 \\
\text { (estimated) }\end{array}$ & $\begin{array}{l}\text { Evaluate the efficacy and safety of T-DMI } \\
\text { plus pertuzumab versus trastuzumab plus } \\
\text { pertuzumab and taxane as adjuvant therapy } \\
\text { in patients with HER2-positive primary } \\
\text { invasive breast cancer following surgery and } \\
\text { anthracycline-based chemotherapy. }{ }^{52}\end{array}$ \\
\hline NCT00833963 & IV & MotHER & $\begin{array}{l}\text { Currently } \\
\text { recruiting }\end{array}$ & Genentech & $\begin{array}{l}100 \\
\text { (estimated) }\end{array}$ & $\begin{array}{l}\text { The MotHER Pregnancy Registry is a cohort } \\
\text { study in women with breast cancer who have } \\
\text { been or are being treated with a trastuzumab- } \\
\text { containing regimen with or without } \\
\text { pertuzumab, or ado-trastuzumab emtansine, } \\
\text { during pregnancy or within } 6 \text { months prior to } \\
\text { conception. }\end{array}$ \\
\hline
\end{tabular}

Abbreviations: HER2, human epidermal growth factor receptor 2; IV, intravenous; MBC, metastatic breast cancer; N/A, not applicable; T-DMI, trastuzumab emtansine; EORTC, European Organisation for Research and Treatment of Cancer; CR, complete remission. 
potential for medication errors and confusion with trastuzumab (Herceptin).

\section{Black box warning for T-DMI}

In the United States, T-DM1 carries black box warnings for hepatotoxicity, cardiac toxicity, and embryo-fetal toxicity. ${ }^{43}$ These side effects are based primarily on data from the EMILIA study. ${ }^{8}$ Serious adverse events were seen in 88 patients (18.0\%) in the lapatinib-capecitabine group and in 76 patients (15.5\%) in the T-DM1 group. Grade 3 or 4 adverse events were $57.0 \%$ in the lapatinib-capecitabine group and $40.8 \%$ in the T-DM1 group. The most commonly reported grade 3 or 4 adverse events with T-DM1 were thrombocytopenia in 12.9\% and elevated transaminases (elevated aspartate aminotransferase in $4.3 \%$ and elevated ALT in 2.9\%). The thrombocytopenia was mostly reported with the first two cycles of treatment and with dose reductions most patients were able to continue treatment. Ten patients (2.0\%) did discontinue T-DM1 because of the thrombocytopenia though. The majority of the patients with elevated transaminases were able to continue treatment. Three patients discontinued T-DM1 because of elevations in ALT. Left ventricular ejection fraction (LVEF) was maintained in $97.1 \%$ of patients receiving T-DM1 (versus $93.0 \%$ in the lapatinib-capecitabine group). Grade 3 left ventricular systolic dysfunction developed in one patient in the T-DM1 group in the EMILA study. ${ }^{8}$ The cardiac safety ofT-DM1 was a concern given the reports of heart failure with trastuzumab; however, significant cardiac problems were not seen in the Phase I and II clinical trials of T-DM1. In the Hurvitz et al Phase II study, one patient in the T-DM1 group developed an LVEF of less than $40 \%$, but no symptoms were reported. ${ }^{42}$ An ongoing Phase II clinical trial with 153 patients enrolled is examining the safety of T-DM1 after completion of anthracycline-based adjuvant or neoadjuvant chemotherapy in patients with early HER2-positive breast cancer. ${ }^{45}$ The preliminary data show that T-DM1 following anthracycline-based chemotherapy was not associated with cardiac toxicity in patients with early-stage HER2-positive breast cancer. The mean LVEF was 67.1\% before chemotherapy and changed little over the course of treatment in the preliminary report; there were no symptomatic decreases in LVEF, but $2 \%$ of patients had an asymptomatic decrease in $\mathrm{LVEF}^{45}$

\section{Phase III clinical trials that are currently underway}

Multiple phase I-III clinical trials are currently underway investigating the use of T-DM1 in breast cancer (see Table 3). While T-DM1 is also being tested in HER2- positive gastric cancer, ${ }^{46,47}$ we will focus our summary on the six large Phase III clinical trials currently underway in patients with HER2-amplified breast cancer. These include the MARIANNE study, ${ }^{48}$ TH3RESA study, ${ }^{9}$ KATHERINE study, ${ }^{49}$ ATEMPT study, ${ }^{50}$ NCT01702571, ${ }^{51}$ and KAITLIN.

The MARIANNE study ${ }^{48}$ is a randomized, three-arm, multicenter, Phase III study that has completed the accrual of 1,095 patients. In this trial, investigators are evaluating the efficacy and safety of first-line T-DM1 in combination with pertuzumab, T-DM1 with pertuzumab placebo, versus a combination of trastuzumab plus a taxane (docetaxel or paclitaxel) in patients with HER2-positive breast cancer (progressive locally advanced, recurrent locally advanced, or metastatic). The primary end point is PFS by independent review facility. ${ }^{48}$ In the similar TH3RESA study, patients were enrolled in this randomized, two-arm, multicenter, Phase III study evaluating the efficacy and safety of T-DM1 in comparison with the physician's choice of treatment. ${ }^{9}$ The study has completed enrollment, with 604 patients enrolled. Patients in this study have advanced HER2-positive breast cancer (metastatic or unresectable locally advanced/recurrent) that has progressed on two or more previous HER2-directed therapies. The primary end points are objective response rate and OS. ${ }^{9}$

T-DM1 is also being tested in patients with early-stage breast cancer. The KATHERINE study is a randomized, two-arm, Phase III study under active participant recruitment. ${ }^{49}$ In this study, the investigators are evaluating the efficacy and safety of T-DM1 versus trastuzumab as adjuvant therapy in patients with HER2-positive breast cancer who have residual tumor present in the breast or axillary lymph nodes following preoperative therapy. ${ }^{49}$ Furthermore, T-DM1 is being tested in small (stage I) HER2-positive breast cancer in the ATEMPT trial. ${ }^{50}$ Women are being randomized to T-DM1 versus paclitaxel/trastuzumab. ${ }^{50}$

The NCT01702571 study is a single-arm, multicenter, Phase III study. ${ }^{51}$ It is currently still recruiting. It is evaluating the safety and efficacy of T-DM1 in patients with HER2-positive locally advanced breast cancer or MBC who have received prior anti-HER2 and chemotherapybased treatment. Patients in this study will receive T-DM1 indefinitely until unacceptable toxicity, withdrawal, or disease progression is present. $^{51}$

KAITLIN is a Phase III multicenter randomized study that will evaluate women with HER2-positive primary invasive breast cancer after receiving surgery and anthracycline-based chemotherapy first..$^{52}$ They will be randomized to T-DM1 plus pertuzumab versus trastuzumab plus pertuzumab plus a taxane as adjuvant therapy. ${ }^{52}$ 


\section{Central nervous system (CNS) penetration}

Both trastuzumab and T-DM1 are large molecules and are not thought to cross the blood-brain barrier. ${ }^{53}$ It has been shown that adjuvant trastuzumab is associated with a significant increased risk of CNS metastases as the site of first recurrence in HER2-positive breast cancer patients. ${ }^{54}$ In a study of 113 women with HER2-positive MBC who had received trastuzumab-based therapy, only $8 \%$ of patients had CNS disease at first diagnosis of metastatic disease; however, 55\% developed CNS disease during the course of the treatment. ${ }^{19}$ In another study, $65 \%$ of women developed CNS metastases during treatment with T-DM1. ${ }^{55}$ Also, in the Phase II study by Krop et al, six patients developed brain metastases as the first site of progression. ${ }^{41}$ There have been some case reports of brain metastases responding to T-DM1. One case report in the Journal of Neuro-Oncology reported a patient with breast cancer who had her brain metastases respond to T-DM1. ${ }^{56}$ Though, there was some concern that the patient in this case report had an impaired blood-brain barrier. ${ }^{56}$ The diagnosis of brain metastases can be catastrophic for patients and continued research is needed in this area.

\section{Potential biomarkers}

As mentioned in this paper, there are now many HER2-directed therapies. However, there is currently not a specific predictive marker to tell us which therapy would

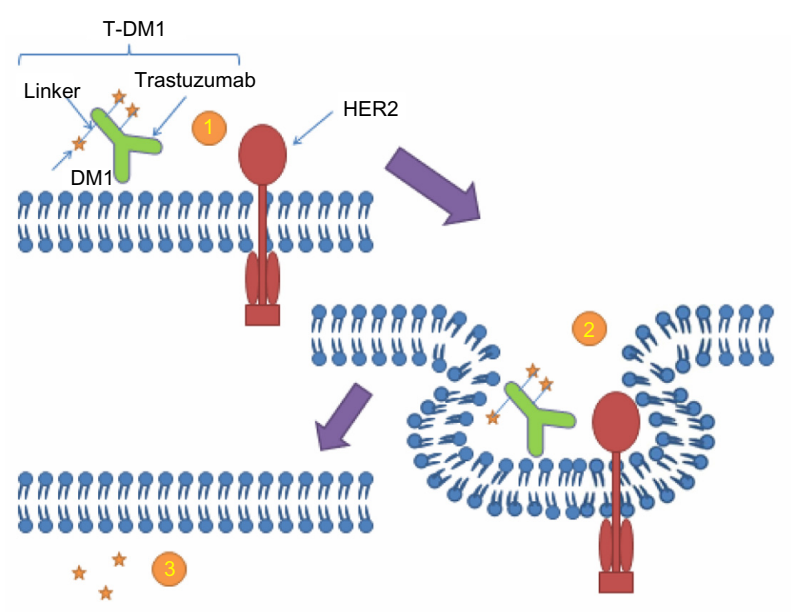

Figure I Mechanism of action of T-DMI

Notes: (I) Trastuzumab retains all of its mechanisms of action. It delivers the DMI chemotherapy directly and specifically to the HER2-positive breast cancer cell. (2) T-DMI is internalized into the HER2-positive breast cancer cell. (3) DMI is released once inside the cell. DMI is a very potent chemotherapy agent that inhibits tubulin development of the mitotic spindle and cell division.

Abbreviations: DMI, emtansine; HER2, human epidermal growth factor receptor 2; T-DMI, trastuzumab emtansine. be the best for each individual patient. Furthermore, there is not a specific predictive marker to predict a patient's response to T-DM1. The EMILIA study had a subanalysis done which looked at the relationship between tumor markers and efficacy. ${ }^{58}$ The authors found that all of the subgroup biomarkers analyzed had longer PFS and OS with T-DM1. However, patients with tumors expressing high HER2 messenger RNA levels had an even greater benefit (in terms of OS) from T-DM1. PIK3CA mutations have been studied in the past and are thought to induce downstream resistance to HER2 therapies. Interestingly, Baselga et al found in the subanalysis that patients with PIK3CA mutations did worse with capecitabine plus lapatinib than those with the wild-type PIK3CA. However, this was not seen with T-DM1, as patients had similar treatment benefit with PIK3CA mutations or wild-type PIK3CA. This suggests that T-DM1 may be able to overcome the PIK3CA mutational resistance. ${ }^{57,58}$

We have extensively reviewed the literature on T-DM1. Its role in treatment is currently limited to its FDA approved indications. ${ }^{27}$ It should be highly considered for treatment of patients with $\mathrm{MBC}$ who progress following treatment with a trastuzumab-based combination regimen, even before other HER2-directed therapies. Though it is not currently FDA-approved for first-line treatment, there is some data in the Phase II clinical trial completed by Hurvitz et al that showed longer median PFS, objective response rate, and less serious adverse events (compared to trastuzumab plus docetaxel). ${ }^{42}$ Though this data exists, larger Phase III clinical trials (KATHERINE, ${ }^{49}$ MARIANNE) ${ }^{48}$ will give us more information about the use of T-DM1 for first-line treatment in MBC. Further studies are also underway to define the role of T-DM1 in adjuvant treatment of early-stage breast cancer (ATEMPT, ${ }^{50}$ KATHERINE). ${ }^{49}$

\section{Conclusion}

In conclusion, there has been significant progress in the development of target therapies for cancer in the past few decades. The development of ADCs, like T-DM1, is particularly promising. It has increased antitumor effect while at the same time improved toxicity. The preclinical and clinical trials show extreme potential for the future of T-DM1 and other ADCs that are likely to come. It is an exciting time for the oncology field and the oncologic treatment of our patients.

\section{Acknowledgments}

Dr Macrae is supported by Translational Training Grant in Experimental Therapeutics 5 K12 CA133250-04. 


\section{Disclosure}

The authors report no conflicts of interest in this work.

\section{References}

1. Giuliano A. Breast Disorders. In: McPhee S, Papdakis M, editors. Current Medical Diagnosis and Treatment. 48th ed. New York: McGrawHill; 2009:630-654.

2. Ross JS, Slodkowska EA, Symmans WF, Pusztai L, Ravdin PM, Hortobagyi GN. The HER-2 receptor and breast cancer: ten years of targeted anti-HER-2 therapy and personalized medicine. Oncologist. 2009;14(4):320-368.

3. Slamon DJ, Clark GM, Wong SG, Levin WJ, Ullrich A, McGuire WL. Human breast cancer: correlation of relapse and survival with amplification of the HER-2/neu oncogene. Science. 1987;235(4785): 177-182.

4. Dawood S, Broglio K, Buzdar AU, Hortobagyi GN, Giordano SH. Prognosis of women with metastatic breast cancer by HER2 status and trastuzumab treatment: an institutional-based review. J Clin Oncol. 2010;28(1):92-98.

5. Kumar G, Badve S. Milestones in the discovery of HER2 proto-oncogene and trastuzumab (herceptin). Connections. 2008;13:9-14

6. Herceptin ${ }^{\circledR}$ (trastuzumab) [prescribing information]. South San Francisco, CA: Genentech; 2014.

7. Tripathy D, Salmon DJ, Cobleigh M, et al. Safety of treatment of metastatic breast cancer with trastuzumab beyond disease progression. J Clin Oncol. 2004;22(6):1063-1070.

8. Verma S, Miles D, Gianni L, et al; EMILIA Study Group. Trastuzumab emtansine for HER2-positive advanced breast cancer. $N$ Engl J Med. 2012;367(19):1783-1791.

9. Hoffmann-La Roche. A study of trastuzumab emtansine in comparison with treatment of physician's choice in patients with HER2-positive breast cancer who have received at least two prior regimens of HER2directed therapy (TH3RESA). Available from: http://clinicaltrials. gov/show/NCT01419197. NLM identifier: NCT01419197. Accessed June 18, 2014.

10. Yarden Y, Sliwkowski MX. Untangling the ErbB signalling network. Nat Rev Mol Cell Biol. 2001;2(2):127-137.

11. Yarden Y. The EGFR family and its ligands in human cancer: signalling mechanisms and therapeutic opportunities. Eur J Cancer. 2001;37 Suppl 4:S3-S8.

12. Hudis C. Trastuzumab - mechanism of action and use in clinical practice. $N$ Engl J Med. 2007;357:39-51.

13. American Cancer Society. Breast Cancer Facts and Figures 2011-2012. Atlanta: American Cancer Society; 2012. Available from: http://www. cancer.org/acs/groups/content/@epidemiologysurveilance/documents/ document/acspc-030975.pdf. Accessed June 18, 2014.

14. Olson EM. Maximizing human epidermal growth factor receptor 2 inhibition: a new oncologic paradigm in the era of targeted therapy. J Clin Oncol. 2012;30(14):1712-1714.

15. Hudziak RM, Lewis GD, Winget M, Fendly BM, Shepard HM, Ullrich A. p185HER2 monoclonal antibody has antiproliferative effects in vitro and sensitizes human breast tumor cells to tumor necrosis factor. Mol Cell Biol. 1989;9(3):1165-1172.

16. Carter P, Presta L, Gorman CM, et al. Humanization of an antip185HER2 antibody for human cancer therapy. Proc Natl Acad Sci US A. 1992;89(10):4285-4289.

17. Slamon DJ, Leyland-Jones B, Shak S, et al. Use of chemotherapy plus a monoclonal antibody against HER2 for metastatic breast cancer that overexpresses HER2. $N$ Engl J Med. 2001;344(11): 783-792.

18. US Food and Drug Administration. FDA expands use of Herceptin for early stage breast cancer after primary therapy [press release]. Silver Spring, MD: US Food and Drug Administration; November 16, 2006. Available from: http://www.fda.gov/NewsEvents/Newsroom/PressAnnouncements/2006/ucm108788.htm. Accessed April 20, 2014.
19. Olson EM, Najita JS, Sohl J, et al. Clinical outcomes and treatment practice patterns of patients with HER2-positive metastatic breast cancer in the post-trastuzumab era. Breast. 2013;22(4):525-531.

20. Baselga K, Cortes J, Kim SB, et al; CLEOPATRA Study Group. Pertuzumab plus trasuzumab plus docetaxel for metastatic breast cancer. N Engl J Med. 2012;366:109-119.

21. Blackwell KL, Burstein HJ, Storniolo AM, et al. Randomized study of Lapatinib alone or in combination with trastuzumab in women with ErbB2-positive, trastuzumab-refractory metastatic breast cancer. J Clin Oncol. 2010;28(7):1124-1130.

22. Blackwell KL, Burstein HJ, Storniolo AM, et al. Overall survival benefit with lapatinib in combination with trastuzumab for patients with human epidermal growth factor receptor 2-positive metastatic breast cancer: final results from the EGF104900 Study. J Clin Oncol. 2012;30(21): 2585-2592.

23. Bross PF, Beitz J, Chen G, et al. Approval summary: gemtuzumab ozogamicin in relapsed acute myeloid leukemia. Clin Cancer Res. 2001;7(6):1490-1496.

24. US Food and Drug Administration. Mylotarg (gemtuzumab ozogamicin): market withdrawal [press release]. Silver Spring, MD: US Food and Drug Administration; June 21, 2010. Available from: http://www.fda.gov/Safety/MedWatch/SafetyInformation/Safety AlertsforHumanMedicalProducts/ucm216458.htm. Accessed June 9, 2013.

25. Gopal AK, Ramchandren R, O'Connor OA, et al. Safety and efficacy of brentuximab vedotin for Hodgkin lymphoma recurring after allogeneic stem cell transplantation. Blood. 2012;120(3):560-568.

26. Pro B, Advani R, Brice P, et al. Brentuxumab vedotin (SGN-35) in patients with relapsed or refractory systemic anaplastic large-cell lymphoma: results of a phase II study. J Clin Oncol. 2012;30(18): 2190-2196.

27. US Food and Drug Administration. FDA approves new treatment for late-stage breast cancer [Internet]. Silver Spring, MD: US Food and Drug Administration; February 22, 2013. Available from: http://www. fda.gov/newsevents/newsroom/pressannouncements/ucm340704.htm. Accessed June 10, 2013.

28. Girish S, Gupta M, Wang B, et al. Clinical pharmacology of trastuzumab emtansine (T-DM1): an antibody-drug conjugate in development for the treatment of HER2-positive cancer. Cancer Chemother Pharmacol. 2012;69(5):1229-1240.

29. Junttila TT1, Li G, Parsons K, Phillips GL, Sliwkowski MX. Trastuzumab-DM1 (T-DM1) retains all the mechanisms of action of trastuzumab and efficiently inhibits growth of lapatinib insensitive breast cancer. Breast Cancer Res Treat. 2011;128(2):347-356.

30. Isakoff SJ, Baselga J. Trastuzumab-DM1: building a chemotherapyfree road in the treatment of human epidermal growth factor receptor 2-positive breast cancer. J Clin Oncol. 2011;29(4):351-354.

31. Higashide E, Asai M, Ootsu K, et al. Ansamitocin, a group of novel maytansinoid antibiotics with antitumour properties from Nocardia. Nature. 1977;270(5639):721-722.

32. Yu TW, Bai L, Clade D, et al. The biosynthetic gene cluster of the maytansinoid antitumor agent ansamitocin from Actinosynnema pretiosum. Proc Natl Acad Sci U S A. 2002;99(12):7968-7973.

33. Wang L, Amphlett G, Blättler WA, Lambert JM, Zhang W. Structural characterization of the maytansinoid-monoclonal antibody immunoconjugate, hun901-dm1, by mass spectrometry. Protein Sci. 2005;14(9):2436-2446.

34. Lewis Phillips GD, Li G, Dugger DL, et al. Targeting HER2-positive breast cancer with trastuzumab-DM1, an antibody-cytotoxic drug conjugate. Cancer Res. 2008;68(22):9280-9290.

35. Erickson HK, Lewis Phillips GD, Leipold DD, et al. The effect of different linkers on target cell catabolism and pharmacokinetics/ pharmacodynamics of trastuzumab maytansinoid conjugates. Mol Cancer Ther. 2012;11(5):1133-1142.

36. Barginear MF, Budman DR. Trastuzumab-DM1: a review of the novel immuno-conjugate for HER2-overexpressing breast cancer. The Open Breast Cancer Journal. 2010;1(1):25-30. 
37. Junutula JR, Flagella KM, Graham RA, et al. Engineered thiotrastuzumab-DM1 conjugate with an improved therapeutic index to target human epidermal growth factor receptor 2-positive breast cancer. Clin Cancer Res. 2010;16(19):4769-4778.

38. Krop IE, Beeram M, Modi S, et al. Phase I study of trastuzumab-DM1, an HER2 antibody-drug conjugate, given every 3 weeks to patients with HER2-positive metastatic breast cancer. J Clin Oncol. 2010;28(16): 2698-2704.

39. Beeram M, Krop IE, Burris HA, et al. A phase 1 study of weekly dosing of trastuzumab emtansine (T-DM1) in patients with advanced human epidermal growth factor 2-positive breast cancer. Cancer. 2012;118(23):5733-5740.

40. Burris HA 3rd, Rugo HS, Vukelja SJ, et al. Phase II study of the antibody drug conjugate trastuzumab-DM1 for the treatment of human epidermal growth factor receptor 2 (HER2) -positive breast cancer after prior HER2-directed therapy. J Clin Oncol. 2011;29(4):398-405.

41. Krop IE, LoRusso P, Miller KD, et al. A phase II study of trastuzumab emtansine in patients with human epidermal growth factor receptor 2 -positive metastatic breast cancer who were previously treated with trastuzumab, lapatinib, an anthracycline, a taxane, and capecitabine. J Clin Oncol. 2012;30(26):3234-3241.

42. Hurvitz SA, Dirix L, Kocsis J, et al. Phase II randomized study of trastuzumab emtansine versus trastuzumab plus docetaxel in patients with human epidermal growth factor receptor 2-positive metastatic breast cancer. J Clin Oncol. 2013;31(9):1157-1163.

43. Kadcyla ${ }^{\mathbb{B}}$ (ado-trastuzumab emtansine) [prescribing information]. South San Francisco, CA: Genentech; 2013.

44. US Food and Drug Administration. Safety Alert for Human Medical Products: Kadcyla (ado-trastuzumab emtansine): Drug Safety Communication - Potential Medication Errors Resulting from Name Confusion [press release]. Silver Spring, MD; US Food and Drug Administration; May 6, 2013. Available from: http://www.fda. gov/Safety/MedWatch/SafetyInformation/SafetyAlertsforHuman MedicalProducts/ucm350817.htm. Accessed June 10, 2013.

45. Dang CT, Gianni L, Romieu G, et al. Cardiac safety in a phase II study of trastuzumab emtansine (T-DM1) following anthracycline-based chemotherapy as adjuvant or neoadjuvant therapy for early-stage HER2positive breast cancer. J Clin Oncol. 2012;30(Suppl 15):532.

46. Hoffmann-La Roche. A study of trastuzumab emtansine versus taxane in patients with advanced gastric cancer. Available from: http://clinicaltrials.gov/ct2/show/NCT01641939?term=t-dm1+gastric \&rank=1. NLM identifier: NCT01641939. Accessed June 10, 2013.

47. Hoffmann-La Roche. A combination study of trastuzumab emtansine and capecitabine in patients with breast cancer or gastric cancer. Available from: http:/clinicaltrials.gov/ct2/show/NCT01702558?term=tdm1+gastric \&rank=2. NLM identifier: NCT01702558. Accessed June 10, 2013.

48. Ellis PA, Barrios CH, Im Y, et al. MARIANNE: A phase III, randomized study of trastuzumab-DM1 (T-DM1) with or without pertuzumab (P) compared with trastuzumab $(\mathrm{H})$ plus taxane for first-line treatment of HER2-positive, progressive, or recurrent locally advanced or metastatic breast cancer (MBC). J Clin Oncol. 2011;29(Suppl 15):TPS 102.
49. Hoffmann-La Roche. A study of trastuzumab emtansine versus trastuzumab as adjuvant therapy in patients with HER2-positive breast cancer who have residual tumor in the breast or axillary lymph nodes following preoperative therapy (KATHERINE). Available from: http:// clinicaltrials.gov/show/NCT01772472. NLM identifier: NCT01772472. Accessed June 10, 2013.

50. Dana-Farber Cancer Institute. T-DM1 vs paclitaxel/trastuzumab for Breast (ATEMPT Trial). Available from: http://clinicaltrials.gov/ show/NCT01853748. NLM identifier: NCT01853748. Accessed April 30, 2014.

51. Hoffmann-La Roche. A study of Kadcyla (trastuzumab emtansine) in patients with HER2 positive breast cancer who have received prior anti-HER2 and chemotherapy-based treatment. Available from: http:// clinicaltrials.gov/show/NCT01702571. NLM identifier: NCT01772472. Accessed June 10, 2013.

52. Hoffmann-La Roche. A study of kadcyla (trastuzumab emtansine) plus perjeta (pertuzumab) following anthracyclines in comparison with herceptin (trastuzumab) plus perjeta and a taxane following anthracyclines as adjuvant therapy in patients with operable HER2positive primary breast cancer. Available from: http://clinicaltrials. gov/show/NCT01966471. NLM identifier: NCT01966471. Accessed April 30, 2014.

53. Abraham J. Trastuzumab emtansine in advanced HER2-positive breast cancer. Community Oncology. 2013;10(3):71-73.

54. Olson EM, Abdel-Rasoul M, Maly J, Wu CS, Lin NU, Shapiro CL. Incidence and risk of central nervous system metastases as site of first recurrence in patients with HER2-positive breast cancer treated with adjuvant trastuzumab. Ann Oncol. 2013;24(6):1526-1533.

55. Olson EM, Lin NU, DiPiro PJ, et al. Responses to subsequent antiHER2 therapy after treatment with trastuzumab-DM1 in women with HER2-positive metastatic breast cancer. Ann Oncol. 2012;23(1): 93-97.

56. Bartsch R, Berghoff AS, Preusser M. Breast cancer brain metastases responding to primary systemic therapy with T-DM1. J Neurooncol. 2014;116(1):205-206.

57. Tessari A, Palmieri D, Di Cosimo S. Overview of diagnostic/targeted treatment combinations in personalized medicine for breast cancer patients. Pharmgenomics Pers Med. 2013;7:1-19.

58. Baselga J, Verma S, Ro J, et al. Relationship between tumor biomarkers (BM) and efficacy in EMILIA, a phase III study of trastuzumab emtansine (T-DM1) in HER2-positive metastatic breast cancer (MBC). Cancer Res. 2013;73(8, Supplement 1):LB-63.

59. ClinicalTrials.gov [homepage on the Internet]. Bethesda: US National Institutes of Health; 2014 [updated April 29, 2014]. Available from: http://clinicaltrials.gov/ct2/home. Accessed April 30, 2014.
Breast Cancer: Targets and Therapy

\section{Publish your work in this journal}

Breast Cancer: Targets and Therapy is an international, peerreviewed open access journal focusing on breast cancer research, identification of therapeutic targets and the optimal use of preventative and integrated treatment interventions to achieve improved outcomes, enhanced survival and quality of life for the cancer patient.

\section{Dovepress}

View the full aims and scopes of this journal here. The manuscript management system is completely online and includes a very quick and fair peer-review system, which is all easy to use. Visit http:// www.dovepress.com/testimonials.php to read real quotes from published authors. 